\title{
AGAMA DJAWA SUNDA (ADS) RELIGIOUS MOVEMENT
}

\author{
Didin Komarudin \\ Usluhuddin Faculty \\ Sunan Gunung Djati State Islamic University of Bandung \\ Email : pakdidin76@gmail.com
}

\section{Abstract}

This study explains that the principles and purposes of the Agama Djawa Sunda - ADS is to serve toward the Lord's command and humanity. ADS believers view religion not just as a belief, but rather as a measure of life. They also interpret religion as humans ruling their act. They call their Lord the Lord Gusti Pengeran Si Kang Sawiji-wiji (the One and Only God). The way they pray to their God is not bound by time and place, it can be done anytime and anywhere because the important point is always rembering God. ADS has titis tulis verse called as "pikukuh tilu" (three powers) that becomes a guideline in everyday life, in relation with God and others.

Penelitian ini memberikan penjelasan bahwa asas dan tujuan Agama Djawa Sunda adalah mengabdi kepada perintah Tuhan dan kepada perikemanusiaan. Penganut ADS memandang agama bukan hanya sebagai kepercayaan, melainkan lebih sebagai ukuran hidup. Mereka juga memaknai agama sebagai aturan gawe manusai (aturan manusia dalam berperilaku). Mereka menyebut Tuhannya dengan sebutan Gusti Pengeran Si Kang Sawiji-wiji. Cara mereka menyembah Tuhannya tidak terikat oleh waktu dan tempat, bisa dilakukan kapanpun dan dimanapun karena yang penting adalah intinya yaitu selalu mengingat Tuhan. ADS memiliki ayat titis tulis yang disebut pikukuh tilu yang menjadi pedoman dan penduan dalam kehidupan sehari-hari, dalam berketuhanan dan bereperikemanusiaan. 
Keywords: Djawa Sunda religion

\section{Introduction}

Indonesia is a heterogeneous nation. There are various tribes, races, cultures and religions within. These differences have positive values, even serves as Indonesian cultural richness sign (Abdullah, 2008: 75). They are commonly known as plurality. Several sociological studies stated that Indonesian society was formed by plurality. It was proven by national philosophy which is taken from regional socio-culture, "Bhinneka Tunggal Ika" (Unity in Diversity).

The plural society is influenced by dominant factors resulting in more complex life. One of the dominant factors is religion. Religion is not an independent entity but comprised of various dimensions. Religion is an integrated unity. Religion diversity in one side is a potential for unity realization. However on the other side we could not deny that it could be a factor that breaks unity. In other words, religion functions as brotherhood embellishment, but as unity breaker as well (Puspito, 1984: 51).

Viewed from historical side, prior to the arrival of new religion, there were several belief systems in Indonesia: religion that put spiritual as God and material as God. Religion that put spiritual as God is usually called as animism while dynamism refers to the religion that put material as God. They considered religion that came from outside as new religion, as it is in contradiction to what they believed for centuries. In a society that strongly believed on ancient heritage value, they are difficult to accept new matters.

In certain societies, custom is considered as belief and frequently associated with religion, and even believed as religion. Therefore, the value of ancient heritage in a belief lesson towards God The Almighty is extremely glorified, resulting the similarity with the value of religion. Upon the monitoring toward mysticism (the science of the inner) by a Javanese belief tradition organization called as Pengawas Aliran Kepercayaan Masyarakat - PAKEM, it was found that there are several forms of mysticism (Santosa, 2010). In Java Island, in 1972 there were approximately 382 mysticism (Subagya, 1990: 90). One of them is Paguyuban Adat Cara Keruhun Urang (PACKU) which was legitimized in 1981 by Prince Djatikusumah (grandson of Prince Madrais). PACKU formerly named Agama Djawa Sunda - ADS (Java Sunda Religion) established by Prince Madrais Alibasa Widjaja Ningrat which was believed as generation of Sultan Gebang 
of Prince Alibasa I in 1848. This strengthens the fact that in Javanese society the tradition is in dialectic link with religion (Roibin, 2013).

Agama Djawa Sunda is one of many organizations for the Experience of Belief in the Almighty God in Ciamis Regency. Beside Agama Djawa Sunda, there are Sumarah Organization, Kebatinan Perjalanan and others whose follower spread in entire Ciamis. According to Koentjaraningrat, many adherents of belief teaching in The Almighty God were due to Javanese attitude and character that always make orientation. Therefore, there were many schools of mysticism that could be viewed from its form and characteristic (1976: 342-343). Almost all Kejawen movements aimed to go through human life perfection.

Prince Madrais journey was a crucial stage in Agama Djawa Sunda history. As from this journey Agama Djawa Sunda and its main lessons were born. At the beginning, Agama Djawa Sunda was established as a resistance form toward VOC. During Dutch colonialism era, Prince Madrais and his ADS was considered as a radical and dangerous group. It is a community of people who were aware of nationality sense. Besides, this was a religion and cultural place for those who had moral responsibility toward their own nation to fight against colonialism.

Agama Djawa Sunda which grew in Ciamis had an interesting history; started from its early establishment, its religious movement and its organization development. These conditions are worth examined to enrich Indonesian culture especially its spiritual culture. This is because in several parts of Indonesia the culture is integrated to religion (Nurdin, 2016). The aforementioned background attracts the researcher's interest to discuss further the Agama Djawa Sunda, especially its religious movement concept. Therefore this research is entitled Agama Djawa Sunda (ADS) Religious Movement (Research in Ciamis Regency of West Java Province).

\section{The Definition of Agama Djawa Sunda (ADS)}

Agama Djawa Sunda (ADS) is a name given by people outside the group led by Madrais. This religion is also known as Cara Karuhun Urang (ancestry tradition), Sunda Wiwitan religion, Madrais percept or Cigugur religion. This Agama Djawa Sunda naming was given as its adherent not only Sundanese but also Javanese since it dealt with nationality values in Java' and Sunda's spiritual tradition. Some said that ADS is abbreviation from Atikan Daya Sampurna (Kepustakaan Nasional, 2013: 33).

el Harakah Jurnal Budaya Islam Vol. 19 No.1 Tahun 2017 
On the other hand, according to Prince Djatikusumah, Agama Djawa Sunda (ADS) is an abbreviation. The word "Djawa" is an abbreviation from andjawat lan andjawab which means to filter, to accommodate, to accomplish and to account for. Meanwhile, the word "Sunda" is an abbreviation from the words Roh susun-susun kang den tunda which means spirits composed in delay or exist in the world. Any living substance is existed and generated by hurip tanah pakumpulan (earth) spirits. The substances in such pakumpulan spirit have power that could influence the life of human being.

Agama Djawa Sunda is an abbreviation from andjawat lan andjawat roh susun-susun kang den tunda. Having meaning to compose and accomplish entire life spirits in the universe with humanity form (Kepustakaan Nasional, 2013: 15). It means that there are various kinds of spirit in this world. Beside human spirit, there are also other spirits living inside goods and God's creatures such as animal, plant, rock, fire, earth, and others. This spirit-related concept extremely influences the entire ADS percept with concept of God they believe in.

The word Djawa Sunda in ADS is not merely intended to certain ethnics, but it is far beyond that. The word Sunda in ADS discussed in Pikukuh Tilu Ajaran Karuhun Urang book. It has three following meanings: philosophical Sunda (sunda dina geter rasa waruga mancuh jadi panyundaan), ethnical Sunda (wujud waruga karsa cipta ti anu Ngersakeun jadi papasten cara-ciri manusa bangsa), and geographical Sunda (wates wangen amparan hirupna bangsa) (Kepustakaan Nasional, 2013: 46-47).

Meanwhile according to Prince Djati Kusumah which is further described in the final project of Ujang Ma'mun, in this context ADS has three meanings. First, ethnical Sunda means all human being who are in Sundanese - speaking community and occupy Bumi Pasundan, Pasundan area. Second, geographical Sunda consists of Sunda Besar (Big Sunda) and Sunda Kecil (Small Sunda). Sunda Besar consist of West Java, Central Java and East Java and Sunda Kecil includes Kalimantan, Sulawesi, Irian and Maluku islands. In other words, geographical Sunda means as archipelago. Third, philosophical Sunda is adjusted with the meaning of Sunda itself, shone (shining). In this context, all people having character that enlighten other people called as Sundanese. In this philosophical Sunda, Madrais referred to the definition of of Sunda in the term of Agama Djawa Sunda (Kristiyanto, 2010).

Religion is mostly defined by experts until certain level. It is closely related to social and cultural construction as reflection of community life structures. In its connection with Agama Djawa Sunda (ADS) which is part 
of kebatinan percept, Wongsonegoro explained that religions are not much connected with human perfection, but related to dogma and ritual matters. He explains that both religion and mysticism have similar element, satu panembah (devotion to The Almighty God) and magnanimity (Rozak, 2005). Its difference is only in its stress or emphasizing in religion, the stress is given to panembah. While kejawen emphasizes the realization of magnimity and life perfectness (Subagya, 1990: 69).

The word religion (agama) in Agama Djawa Sunda is not intended to form new religion or add the existing ones but more to live religious percept growing today. It is based on the manner and characteristic of human, nation and unity as well as making the best effort to deepen the religion expectation. Religion concept used by the followers to refer to the term of ADS frequently called as aturan gawe manusa or human behavior regulation (Kepustakaan Nasional, 2013: 38).

The principle and purpose of Agama Djawa Sunda are devoting toward God's order and humanity. The well-known expression from ADS is sampurnaning hirup, sajatining mati (perfect life, true dead). Human being should not merely memorize and understand their intelligence but also direct their deeds and behavior toward God's order. ADS adherents consider religion not merely as belief, but more as life measurement. With religion, they usually measure whether or not life has aligned toward God's and humanity order.

ADS adherents believe that human is the most perfect God's creature. They believe that human being consists of two dimensions, physical dimension (physic) and spiritual dimension (mental). Physical dimension is equipped with senses. Meanwhile spiritual dimension is equipped with sir, feeling and thought which are triangtu in human being. Sir is instinct or desire, feeling is feeling and thinking is ratio. This spiritual dimension that becoming trigger to control physical dimension. By that way, religion appreciation does not result in narrow fanaticism, but truly becomes the breath of life, veins in someone's life.

\section{History and Development of Agama Djawa Sunda}

Agama Djawa Sunda was formed in 1848 at Gebang, Eastern Cirebon. ADS founder was Prince Sadewa Madrais Kusuma Wijaya Ningrat. He was son of Prince Alibassa I, Sultan from Gebang Kingdom. ADS is frequently called as Madraism considering Madrais as its founder. The followings are complete Gebang's family tree: 1) Prince Wira Sutajaya, 2) Prince Seda Ing 
Demung, 3) Prince Nata Manggala, 4) Prince Seda Ing Tambak, 5) Prince Seda Ing Garogol, 6) Prince Dalem Kebon) 7) Prince SutajayaUpas, 8) Prince Sutajaya Kedua, 9) Prince Alibasa Kusuma Wijaya Ningrat (Kepustakaan Nasional, 2013: 18).

The name of Madrais came from Muhammad Rais, a name that is identical with Islamic culture. He spent his youth in Islamic boarding house . This was the influence of the grandfather from his nanny's mother side. This name was not given by his adherents and students, but from people outside his adherents. It came from "maduning rasa ing sajati" which means human with true sense and feeling, compassionate spirit and magnanimity. Accordingly, alongside with his traits Madrais was a precedent.

Prince Madrais was not born in Gebang, but in Susukan, Ciawi, Gebang. Since childhood he was entrusted at Kuwu Cigugur, Ki Sastrawardana from Mataram Kingdom of Prince Harja Semeru descent. He was taken care and appointed as son by Ki Sastrawardana, so that he could continue his ancestor's struggle in their effort to resist and fight Dutch colonialism. Kiai Madrais did not make direct fight physically or power struggle, but with soft and smooth ways. It was done specifically by reinvesting unity spirit and national personality and always obliged his adherents to respect their national cultural characteristics. The awareness on nationality is prerequisite of national unity and integrity senses. Each of the teaching of Madrais always inserts and emphasizes on nation cultural elements. In order to make his adherents more unite and commit, he subsequently founded a religion named Agama Djawa Sunda mostly known as ADS (though by Dutch colonial government, his teaching was categorized as adat recht or custom law) (Kepustakaan Nasional, 2013: 37).

At the age of 10, Madrais was known as Taswan. He worked for kuwu Sagarahiang as Buffalo's shepherd. As he grew up, he made journey to several paguron, a place for study especially about religion, in Java Island. Yet as he reached age of 15, he got insight to find the true nature of a religion. After years he moved from are paguron to others, he came back and built his own paguron in Cigugur. He then became a teacher who knew the self or understanding life and living substance. His adherents called him as Kiai Madrais. He was known as a smart, authoritative, religion-knowledgeable, and influential person that his adherents considered him as a precedent (Kepustakaan Nasional, 2013: 37).

Prince Madrais' journey was a crucial stage in ADS history, as from that journey ADS and its main teaching were born. During the Dutch colonial era, Prince Madrais and his ADS were considered as radical and dangerous 
group. ADS leader was arrested in Kuningan and Tasikmalaya, but he was released thereafter. From 1901 through 1908 ADS leader was exiled to Meraoke with accusation as rebel and community's blackmailer. Upon return from seclusion, he redeveloped his adherents. It was turned out that they got even more radical in defending and executing its religion teaching as they were left by their leader. Dutch government considered ADS was more dangerous, therefore Prince Madrais was arrested again and put into mental hospital at Cikeumeuh, Bogor. This arrest turned out to escalate ADS group solidarity not to surrender to the condition. During his stay at mental hospital Prince Madrais was not stop teaching, though only teaching mental hospital patients. From this condition, ADS leader was released from the hospital as government were worried that the patients could be influenced by his teaching that was considered radical. Such ADS leader's releasing was followed by threat not to carry out religious activity anymore. For that intention, ADS leader residence that was also served as ADS activity center was strictly guarded.

In 1926 all Dutch officers in Cigugur were withdrawn and reassigned. ADS was then allowed to carry out its activity again legally. Even in 1927 ADS marriage procedure was accepted by law. From one side this period could be considered as enlightenment period for ADS as they got no barrier from Dutch government side. But on the other side it was the beginning of new difficulties, as rumors emerged that Prince Madrais and his ADS were in partnership with the Dutch, and even considered as Dutch's accomplice.

Beside being known in Cigugur, Kiai Madrais was also known as a smart and influential figure in Heubeul Isuk Pesantren and in Ciwedus. Even Kiai Madrais Islamic Boarding school also teach Islamic religion and spirituality to its student. Besides, they were also taught to be more respectful to their national tradition and characteristics (Java Sunda). In this teaching, he emphasized on national awareness as basic awareness and faith to God. Growing belief that truly believe, understand and could sense God's majesty as well as realizing life function as human being and as a nation.

Apart from teaching Islamic religion, he also described other religion percept to be reassured. There is a similar point among those religions in believing The Almighty God which becomes basic of humanity awareness in realizing love for others. Likewise awareness on nationality is stated as ultimate prerequisite for the realization of a nation's unity and majesty (Djatikusumah, 2000: 6). As he was extremely emphasized on nation cultural elements in his teaching, then it was said that Kiai Madrais formed Agama Djawa Sunda. This 
term was not intended to add the number of religion, but more to realize awareness on national culture and learning the said religion percept.

Prince Madrais died in 1939, then ADS leadership was succeeded by his son Prince Tedjabuana Alibasa Kusuma Widjaja Ningrat (Kepustakaan Nasional, 2013: 42). In this leadership ADS was faced with various huge challenges. First, as Japan entered Cigugur, accusation that Madrais and his adherents were Van der Plas accomplice were even stronger. Under the threat of Japan military leader, ADS leader was forced to sign ADS dismissal statement letter. Considering safety of his adherents from various persecutions, new ADS leader agreed the signing of such statement letter. He himself and his family evacuated to Bandung and subsequently headed to Tasikmalaya. From there, ADS leader asked for adherent's affirmation to remain survive or surrender. ADS adherent spirit remained strong in spite of the pressure.

ADS adherents frequently considered Japanese ruler's suppression as product of provocation of those not favoring their existence. Such consideration aggravated ADS adherent's relationship with the surrounding Islamic adherents. In 1947 Cigugur was ruled again by Dutch soldiers. On December 21st, 1954, ADS activity center was attacked and burnt by DI/TII soldiers. Though such burning did not fatal in nature as it was only devastated rear side of the building, it was quiet intimidating psychologically. Upon the incident, Prince Tedjabuana and family decided to move to Cirebon. From this place his leadership was carried out. In 1956 Kiai Madrais guidance or Agama Djawa Sunda was registered in Indonesian Mysticism Coordination Board (BKKI). Madrais guidance was more intensified and Cigugur served as ADS development basis (Kepustakaan Nasional, 2013: 38).

Since then ADS adherents could carry out their religious activities hardly without obstacles. Eventually in 1960s Agama Djawa Sunda Development was over. ADS then dissolved by PAKEM (Community Belief Teaching Supervisor) as ADS was not considered as religion. It was even considered as deviation from religion (Islam) teaching. Due to such incident, there is a similar point among those religions in believing The Almighty God which becomes basic from humanity awareness in realizing love for others. Though subsequently some converted to Islam, Christian, Hindu and Buddha, some others still remained on their belief. With so many ADS adherents converting to Catholic, then Catholic Church activity began in Cigugur. Alongside making guidance of Catholic's values and way of life, church also carried out other activities aimed to make education, health and economic condition of the people 
better. It turned out that these activities got good responses with no significant problems, either from government or local community.

During Prince Tedja Buana (son of Prince Madrais) leadership, the guidance of symbols and languages given by his ancestors were started to be explained and described openly. Therefore Prince Tedja Buana received Rama Pangwedar title from his adherents (Kepustakaan Nasional, 2013: 39).

Upon Prince Tedja Buana, ADS leadership was succeeded by Prince Djati Kusumah (son of Prince Tedja Buana or Grandson of Kiai Madrais). In this era the teachings were more discussed and deepened and associated with today's reality. Humanity teaching's guidance that is full of symbol and meaning received more concrete and touching explanation in every side of human life. Around 1960s (exactly at Prince Tedja Buana leadership) ADS development was over. ADS was then dissolved by PAKEM (Community Belief Teaching Supervisor) as ADS was not considered as religion and even as deviation from Islamic religion and having no holy book guidance such as other religions.

\section{The Entrance of Agama Djawa Sunda to Ciamis}

Kertajaya Village had socio-cultural life system that reflects the diversity of religion or belief in a rural region. The society of Susuru, a part of Kertajaya, filled their religion sector with the humanity values. They were so intense in maintaining the togetherness in their everyday life. They prioritized the harmonious life without considering any different religion and belief background. Their sociocultural life was considered as a unique matter by the society. According to various sources, religion and belief leaders, all of the Susuru citizen were moslem. But in the first half of 20th century, one of Susuru resident, Ki Sumarta, headed into Cigugur to study at Paseban Tri Panca Tunggal Building (Madrais Padepokan). He eventually took the new percept which was known as ADS. Today it is known as Adat Karuhun Urang which was brought by Ki Sumarta and Ki Adnasan. Whereas Ki Sumarta was born in Sadewata and came from a influential family in his region, he was then married a Susuru citizen and stayed in Susuru. According to the story, he built a house in an extremely haunted place and no one even dare to stay there, it was Ki Sumatra, the first person dared to stay there.

In 1860s, Ki Sumatra studied in an Islamic Boarding School in Lumbung for seven years. He then continued his education in Panjalu for another seven years as well as he did not find what he was looking for, knowledge of heaven,

el Harakah Jurnal Budaya Islam Vol. 19 No.1 Tahun 2017 
hell and humanity. He kept on continuing his journey while trading in order to get the knowledge he was looking for. Based on his teacher's instruction, he headed pesantren in Cirebon and studied for 3 years. As he had not obtained the knowledge he was looking for, he followed his teacher's instruction to go to Cigugur. He intuitively found that place after he visited Cagerlah.

He eventually attained science he was looking for in Kiai Madrais Pesantren and met Ki Adiwijaya whom also known as Ki Adnasan. Adiwijaya/Adnasan was a Cinyasag resident who was also a religion speaker. As he realized that his knowledge on religion was not good enough, he continued to study in a boarding school in Lumbung while he make trading. Since he thought that he did not attain what he was looking for, following his teacher's instruction, he continues his study to Panjalu then to Kudu Gede, to Cirebon, and finally to Cigugur. In this city, he found a Kiai Madrais Boarding School, which was also known as Siduru Isuk.

After Ki Sumarta and Ki Adnasan attained the knowledge that they were looking for, they went back to their hometown. They shared their knowledge to their friend, namely: 1) Mr. Arnawijaya, 2) Mr. Antawijaya, 3) Mr. Sukarta, 4) Mr. Sanhuri, 5) Mr. Karta Jumad, 6) Mr. Santaip, and 7) Mr. Elon/Sukarja. In 1880 Ki Sumara's percept was rapidly grown in Susuru and most of Susuru resident became his adherents. Such percept developed into Lumbung and Panjalu region. In 1917, Prince Madrais came to Susuru and performed a ritual by using banana trees in Pager Gunung block street and said "every dead human being should be rested by using coffin (teak coffin)". This was meant to differentiate human being and animal. Therefore, coffin must be used in the mortal remains' funeral. After the ritual, he headed to $\mathrm{Ki}$ Sumatra's house and made furnace around his house which were used to cook. He said that all cooked food must be consumed and anything left must be burnt in the furnaces. Then he celebrated it with a Nayub Party for seven days and nights.

On August 1925 (12 $2^{\text {th }}$ of Maulud), Madrais adherents in Sasuru were attacked by a group of people from Lumbung, Kawali, and Ciamis. The attackers were a group of people from Lumbung, Kawali and Ciamis. This attack happened since they got competition with the former Lumpung adherents who then become Madrais' adherents. This attack happened since they got competition with the former Lumpung adherents who then becoming Madrais' adherents where male residents run into Cigugur and female residents arrested in the Office of Religious Affair. In 1942, ADS adherents were threatened by colonial 
accomplices and forced to convert to Islam, which actually the adherents were all moslem. According to Kirata language, Islam meant Isi Alam while some said that it was Insan, Sufiyah, Lawamah, Amarah, and Muthmainnah. The ADS adherents principally had applied islamic percept though it was different from their confession. They still remained moslem, for having the similar characteristic mentioned before. Ancient time elderly had deeper interpretation as product of years of Islamic boarding school education.

Belief is something that could not be forced, ordered and restricted, as it is a personal matter that could not be obstructed and influenced. It is a part of social form constructed as the societal theology applied in their behavior (Komarudin, 2016). It is their own behavior instead of their belief that saved them. As mentioned by Mr. Dayat, "“naon wae agemanana nu penting mah tingkah paripolahna, teu kudu jauh-jauh ningali ke jaga, ayeuna ge bisa ditingal balesanana, lamun urang tingkahna hade nya tangtu bakal meunang nu hade deui." (whatever the religion/belief) it is the behavior that matter, it is not necessary to observe far beyond of time, right now we could see the return, should we have excellent behavior then we must receive good return as well (Interview with Mr. Dayat, Sunday, February 2nd, 2016).

He further explained: "Tapi kanyataan ayeuna mah geus tibaralik, anu ku hukum adat diarang tapi ayeuna mah malah loba nu mikaresep. Contona we si aril, ceuk hukum adat jeung kayakinan oge nu di lakukeun ku manehna teh goreng, tapi dina kanyataanana sanggeus kaluar ti bui geuning kalah loba nu mikaresep, tah tibalikna zaman ayeuna." [But nowadays the reality is upside down, many interested in something restricted by custom law. Take a look Ariel Noah case (of pornographic act) for the example, what he did was bad according to custom law and belief, but in fact, after released from the prison many people still like him] (Interview with Mr. Dayat, Sunday, February 2nd, 2016).

Then 1964 ADS disbanded themselves, but some said it was dissolved by the government. Madrais leadership then succeeded by Prince Tedja Buana. He asked his adherents to take shelter in Camara Putih (they temporarily must convert to Catholic). At that moment ADS adherents were agreed to convert to Chatolic and study the Holy Bible. Then in 1981 loyal adherents of ADS, who formerly converted to Catholic joining PACKU (Paguyuban Adat Karuhun Urang). But then PACKU was also disbanded since it was considered as neoMadraism organization. After that, Prince Djatikusumah collected his loyal adherents to be bounded in one community called as Adat Karuhun Urang

el Harakah Jurnal Budaya Islam Vol. 19 No.1 Tahun 2017 
community (AKUR) (Interview with Mr. Dayat and Mr. Juhri, February $2^{\text {nd }}$ 2016).

\section{Agama Djawa Sunda Religious Movement}

Religious nature of every human being is an instinct that triggers their hearts to carry out holy acts inspired by The Almighty God. It has holy characteristic in which through the heart they openly received the existence of God (Moreno, 1994: 128). Thus, it is clear that human instinct have readiness to identify and believe the existence of God. In other words, recognition and knowledge of God are actually strongly inherited in every human nature but combination with physic makes them busy in fulfilling their needs. Expectation, temptation and deceit of the world make human weak.

Shadra also explained that in connection with knowledge of God basically is a natural matter. Understanding of compulsory form is a natural matter because when human encounter frightening and complicating problems, they instinctively put their belief of Allah. In such conditions, they automatically turned into form as source of entire causes and simplify any difficulties (in Beheysti, 2003: 32). Belief toward something sacred makes it treated specially. There are treatment procedures for something sacred, there are religious ceremony in facing with the sacred one. These ceremonies and treatments could not be specifically understood economically and rationally. It is carried out by primitive people from long time ago until today and in the future (Pritchard, 1984). Such irrational ceremonies are called as rites in English term which means religious action or ceremony (Agus, 2007: 96).

Ritual or rites connect to supernatural power and something sacred. Therefore rites or ritual terms are understood as religious ceremony. It is completely different from natural, profane, economical and daily rational activity. In religion, ritual ceremonies are usually called as worship, devotion, praying or sembahyang. Religion tendency teaches many worships in daily life which is intended to always contact with their God.

Every religion has its own way in pronouncing and worshipping its God. In understanding God, Agama Djawa Sunda adherents mention their God as "Gusti Pangeran Si Kang Sawiji-wiji" (Interview with Mr. Dayat, Sunday, February 2nd, 2016). It is different from Mr. Juhri who stated that no special pronouncing to their God, it is enough to just call Gusti (Interview with Mr. Juhri, February 2nd, 2016). When Mr. Dayat was asked concerning the meaning of Gusti Prince Si Kang Sawiji-wiji, he answered that there was no 
special meaning as it was only different naming as God that is believed by any religion is the same God, The Almighty God, The Merciful God. He further explained that God is The Justice and His fairness is proved by His creation of various nation with different characteristic.

Agama Djawa Sunda does not limit the worshipping to God, as explained in Pikukuh Tilu book: "Soal ibadah anjeuna (Madrais) mere kabebasan, kucara kumaha wae meunang, nu penting mah intina (esoterikna), dina prak-prakanana nyembah ka Anu Maha Kawasa, anjeuna mah ngan ukur ku cara semedi basana "ngedeuheus tanpa ngalengkah, unjukan tanpa ngucap", kitu oge teu ka uger ku waktu reujeung tempat." [Madrais gives freedom in terms of worship, the means of worshipping does not matter and the point is in its point in worshipping practice to the Almighty God which be done by semedi and it is not limited by time and space].

Spirituality has nationality insight and plural in nature. Sang Seuwu Karma religion teaches wisdom in managing human being life by the guidance of the following Dasa Panta: (Masyarakat Adat, 2016).

a. Guna (Purpose), carrying out something must be explained its usefulness both for the ruler and the ruled one

b. Ramah (Kind), kindness must be accompanied in commanding certain matter,

c. Kagum (Fascinated), command delivered must be in accordance with the commanded one,

d. Pesok, reureus, pleased means the commanded must be pleased in carrying out what has been commanded,

e. Asih, a command must be based on love so that the task would be considered as mutual responsibility,

f. Karunya, love, full of love, command could be sensed by the commanded and resulting in confidence so that the task would be carried out wholeheartedly.

g. Mukpruk, by soft attitudes and words the commanded one would not consider themselves being forced.

h. Ngulas, commenting, warning, and correcting the work result might be needed but must be given wisely to not hurting other's feeling,

$i$. Nyecep, reassuring by respecting others' hard work,

j. Ngala angen, the commander should be able to attract sympathy from the commanded, making the commander to be always respected. 
By following those guidances, they do not limit themselves in performing their worship to The Almighty God. Their worship rituals are not bounded by space and time. It could be done anytime and anywhere as the ultimate matter would be always remembering God. Though they do not limit themselves in terms of worship, there is special ritual carried out at dawn and in the dusk. Their worships would be by maintaining attitude and monitoring the limbs in performing its functions.

It was further explained: "teu aya batesan dina halna ritual ibadah mah, tapi aya anu secara khusus sok dilakukeun dina waktu peuting menjelang siang jeung siang menjelang peuting. Tapi dina prak-prakan sapopoena teu di batasi ku waktu jeung ku tempat. Kolot sok nyarita, kade tah poho nu lima waktu, nyebut lima waktu tapi teu di batesan ku waktu. Maksudna ayana panon, dina waktu ningali lamun kira-kira lain tempoeun ulah stempo-tempona, kitu deui panca indera nu sejenna." (Interview with Mr. Dayat, February 2nd, 2016). [There are no limitations in worship ritual, but there is special ritual carried out at dawn and in the dusk. But on daily practice, they are limited by space and time. Elder people left message not to forget to the five times, mentioning five times do not mean limited by time. In other words, eyes must be maintained as seeing something not worth seeing, likewise with the other senses].

ADS adherents' worshipping to God is done directly through prayer, semedi, or making spiritual dialogue. It could be also carried out indirectly through charity to others, upholding nation and the country, and obeying the prevailing regulation. One of the interesting matters in ADS is the semedi method, as they call as Nyipta Sisakapura (Kristiyanto, 2010: 188). In semedi, someone tries to see and present their own face as meditation materials. This kind of semedi is quite challenging to do, therefore, loyalty and passion are necessary to attain devoted semedi level.

\section{The Prophetical Function of Agama Djawa Sunda}

In terms of Abrahamic religion, prophets are those receiving revelation concerning its religion and mission. In Jewish and Christian tradition, prophets are leaders called by Allah to warn people from deviating God's order. A successful prophet never acted as the one delivering rational opinion or intellectual logic thinking person instead as the restorative person. Prophetical refers to those with their special comprehension and intelligence, receiving certain teaching from The Creator of Universe that obliges them to deliver it or entire human being. These incredible intelligence and comprehension 
are usually termed as revelation (Beheysti, 2003: 89). A prophet must be able to gain support from his people. Otherwise, it is unlikely that their teaching could reach another group of people. When distortion happens, they are obliged to correct it (Rahman, 1980: 117).

\section{Agama Djawa Sunda Holy Book}

ADS adherents do not have written official holy book. But they have kitab hayat, ayat titis tulis that become their daily life guidance. These ayat titis tulis became God - based humanity law and called as pikukuh tilu. Pikukuh tilu means three fortitudes that become men's life guidance to reach human perfection (Sukajadi, 1993).

Pikukuh tilu includes: Ngaji badan, Mikukuh/iman kana tanah, Madep ka ratu-raja 3,2,4,5 lilima 6. First, Ngaji Badan. Ngaji means to review, filter, select, correct or understand, meanwhile Badan means any universe element that causes human exist and sensed by the five sense. Ngaji badan means people should be able to correct or comprehend anything around us, able to sense what others do (Kepustakaan Nasional, 2013: 47). Through ngaji badan or ngaji diri, human being shall be able to recognize and always be able to correct themselves remaining on their humanity characters. Ngaji badan is also nothing but self-reading by discovering or improving and monitoring individual behavior.

Second, Iman Kana Tanah which means striving to remain loyal to the homeland (nation). Land (Tanah) here is classified into two: tanah adegan and tanah amparan. Tanah adegan is body, physic, self, meanwhile tanah amparan means water and its life that lead into prosperity. Human beings have their own prominence, trusted by God to process universe elements. We as human being are created by God as part of the nation who must be able to respect and honor and love our own nation.

Third, madep ka Ratu Raja 3,2,4,5, lilima, 6. Madep means facing and madep ka Ratu Raja here has symbolic meaning. Raja means ngarajah, ngawincik or maintain, meanwhile ratu means ngajagat rata. Ngiblat Ratu Raja has final purpose of ngajagat rata which means creating balance in men's life and universe. Ratu 3 is implementation of tritangtu na raga: sir-rasa-pikir, tri tangtu fi nagara; rama Resi Prabu, tritangtu di buwana, Creation-Sense-Intention. Ratu 2 means balance law, harmony in life two human characteristic of male and female. These two characteristics exist and unite in every of human being. Ratu 4 means hand and leg, we should be aware of two hands and two legs 
behaviour. Ratu 5 is interpreted as five senses, in which we should always be aware of this five senses influence. Ratu lilima is bias of five senses, eyes with its sight, ear with its hearing, mouth with its words, nose with its smelling, and skin with its touch (Kepustakaan Nasional, 2013: 73).

In the book of Pikukuh Adat Karuhun Urang (Spiritual Culture Description), what is meant by ratu lilima is that The Almighty creates five nations, Walanda, Hindu, Arab, Chinese, and Indonesian with their own national characteristic (Djatikusumah, 2000: 33). Ratu 6 is realization of a personal sisakarupa which have been inherited both as human being and as a nation. By strongly uphold the pikukuh tilu, human being shall always be careful and aware in making action as pikukuh tilu is based on reality. As human gifted with feeling, they should sense and realize their behavior based on regulation available in pikukuh tilu.

\section{Life movement after death}

It is explained in pikukuh tilu: Adat Sunda karuhun henteu nerangkeun alam supranatural (gaib) sabada manusa dipundut ku anu Rahayu di ala ku Sanghyang Maha Kersa. Silokana lir ibarat urang melak buah, kumaha cara melak, prak digawe kaasup mulasarana. Perkara jadina tangkal anu alus henteuna gumantung bibit, kaayaan tanah jeung cara ngurus."(Kepustakaan Nasional, 2000: 62).

In discussing period between death and judgement (alam kubur), ADS teaching do not discuss life after death, as explained by Mr. Dayat: "Adat karuhun teu nerangkeun alam supranatural (gaib), alam kubur di ADS disebut alam kalanggengan, $\mathrm{ka}$ abadian. It is hard to explain, as belief relates to personal comprehension. When people died many would say "May he/she rest in peace by God. I do not want to get such expression as logically if we are by God's side then we should attain place that is far from God. I want to be one with God, not only by His side. According to the proverb, purkatut which means from God and return to God.

\section{The Social Movement of the ADS Adherents Toward Nearby Society}

Kertajaya society has socio - cultural life that reflect religion's unity in diversity. It is full of humanity and togetherness. They live by maintaining the togetherness values in the society, nation, and country. They prioritize more on harmonious life without noticing the different background of religion and belief. Though such actions in Fiqh are considered as deviation, they still put the humanity values more than the ritual formality. 
Social interaction is in the form of dynamic social relationship and related to individual relationship, group relationship, as well as between individual and group in a society. Kertajaya still has gemeinscaft or community (paguyuban) characteristic. In paguyuban there is a common will, understanding and principle emerges from such community (Soekanto, 2009: 118).

Kertajaya society has a remarkable religious tolerance. They live by respecting and honoring one and another. Even though they have different religion, worship method and worship place. The religious tolerance could be noticed from the existence of worship place of each religion and belief in Dusun Susuru. Though Moslem' and Catholic's worship places are close, they do not have objection or feel uncomfortable with the close distance. Relationship between religion people in Kertajaya are carried out through daily life activities, society activities and organizational activities and activities in organization. Daily life activities take form of relationship in social interaction and work relationship as well. Aside from religious social relation, Kertajaya society also has strong brotherhood relationship pattern. Family structure in this village showed that based on the religion they believe, they do not have to be in one community. In other words, the ancestors and the generation might have different religion.

Conflict of religion or belief was hardly happen in Kertajaya as explained below: "Lebah dieu memang teu ngabeda-bedakeun, teu nanaon dina pangakuan sewang-sewangan ge, tapi aya dina sapangartian. Ayana perbedaan dina keyakinan teu nanaon da eta mah hak masing-masing, teu bisa dipaksakeun. Sok teu ngarti lamun aya pertentangan, da naon nu rek di pertentangkeun dan sadayana ge hasil ciptaan $\mathrm{Nu}$ Kawasa, sarua pengersa, da teu dikersakeun mah moal aya manusa. Sadayana ge di kersakeun dan sarua teu bisa milih-milih, hayang kumaha jeung dilahirkeun dimana na. Gusti ge teu ngabeda-bedakeun contona we dina nafas. Nu diidep ku manusa, ku reungit, kusato jeung sajabana kan teu di pilah-pilah, sarua aya dina katunggalan. Jadi teu kudu aya pertentangan da sarua sadayana ge hasil pangersana Gusti" (Interview with Mr. Dayat, February 2nd, 2016).

Therefore, according to Mr. Dayat, it was not appropriate to debate something as everything in this world is God's creation. Behaviour and devotion are the only things that differentiate one man with another. Human being as social creature that always needs each other should live in harmony without making any discrimination because every human being is God's creation.

el Harakah Jurnal Budaya Islam Vol. 19 No.1 Tahun 2017 


\section{Conclusion}

According to research result it could be concluded that Agama Djawa Sunda was born in 1848 in Gebang, Eastern Cirebon. ADS founder was Prince Sadewa Madrais Kusuma Wijaya Ningrat, who then suceeded by his son Prince Tedjabuana Alibasa Kusuma Widjaya Ningrat and by Prince Djatikusumah until today.

Agama Djawa Sunda is abbreviation of andjawat lan andjawab roh susunsusun kang den tunda which means compiling and perfecting entire life spirits in the universe with humanity realization. Religion is closely related to social and cultural constructions that are reflection of supporting society life structure. For ADS adherents, religion means aturan gawe manusa or human behavior rule. Life spirituality of ADS adherent cristally in one siloka Tri Panca Tunggal which is culmination and tangency point between The Almighty (Gusti Yang Widi Wasa) and micro cosmos (human being) and macro cosmos (the universe).

Every religion has its own ways in calling and worshipping its God. In understanding God, Agama Djawa Sunda calls their God as "Gusti Prince Si Kang Sawiji-wiji. Their worship forms to God are not limited by space and time. This belief does not recognize prophet since Madrais though becoming the messenger he was just called as pinisepuh or the elder. ADS adherents also do not have written official holy book,-but they have kitab hayat, ayat titis tulis that become their life guidance in daily life and their God - based humanity law, called pikukuh tilu. This belief does not identify life after death and alam kubur as well, but it has alam kalanggengan. Since Adat sunda karuhun does not describe supernatural nature after human being's life taken by The God Almighty, the return of every behavior could be noticed from their attitude during their life span.

\section{References}

Abdullah, Irwan dkk, 2008. Agama dan Kearifan Lokal dalam Tantangan Global, Yogyakarta: Pustaka Pelajar.

Agus, Bustanuddin. 2007. Agama dalam Kehidupan Manusia, Jakarta: PT RajaGrafindo Persada.

Beheysti, Muhammad Husaini. 2003. Mencari Hakikat Agama-Panduan Rasional bagi Manusia Modern. Bandung: Arasy. 
Djatikusumah, P. 2000. Pikukuh adat karuhun urang (pemaparan budaya spiritual), Kuningan: Yayasan Trimulya.

Kepustakaan Nasional RI: Katalog dalam Terbitan (KDT), 2013. Cigugur-Miniatur Pluralisme Indonesia, Bogor: Lembaga Pengkajian Kebudayaan Nusantara.

Komarudin, Didin. 2016. Bisnis Orang SUnda: Studi Teologi dalam Etika Bisnis Orang Sunda. El Harakah 18(1), 93-108.

Kristiyanto, A. Eddy. 2010. "Madraisme: Memapar Khazanah Rohani Agama Djawa Sunda" dalam Spiritualitas Dialog: Narasi Teologis tentang Kearifan Religius, Yogyakarta: Kanisius.

Masyarakat Adat Karuhun Urang Sunda, 2008, Pemaparan Singkat: Jejak Sejarah Komunitas ADS (Agama Djawa Sunda) ke Komunitas AKUR (Adat Karuhun Urang), di kelurahan Cigugur Kecamatan Cigugur, Kabupaten Kuningan, Jawa Barat.

Moreno, F. Francisco Jose., trsl. Amin Abdullah, 1994. Agama dan Akal Fikiran I Jakarta: Raja Grafindo Persada.

Nurdin, Abidin. 2016. Integrasi Agama dan Budaya: Kajian Tentang Tradisi Maulod dalam Masyarakat Aceh. El Harakah 18(1), 45-61.

Pritchard, E. Evans. 1984. Teori-teori tentang Agama Primitif, Yogyakarta: PL2M Pusat Latihan, Penelitian dan Pengembangan Masyarakat.

Puspito, Hendro. 1984. Sosiologi Agama. Yogyakarta: Kanisius.

Rahman, Fazlur. 1980. Tema Pokok Al-Qur'an, Bandung: Pustaka.

Roibin. 2013. Dialektika Agama dan Budaya dalam Tradisi Selamatan Pernikahan Adat Jawa di Ngajum, Malang. El Harakah 15(1), 34-47.

Rozak, Abdul. 2005. Teologi Kebatinan Sunda, Bandung: Kiblat.

Santosa, Iman Budhi, 2010, Nasihat Hidup Orang Jawa, Yogyakarta, Penerbit Diva.

Soekanto, Soerjono. 2009. Sosiologi Suatu Pengantar. Jakarta: Rajawali Press.

Subagya, Rahmat. 1990. Kepercayaan, kebatinan kerohanian kejiwaan dan Agama, Yogyakarta: Kanisius.

el Harakah Jurnal Budaya Islam Vol. 19 No.1 Tahun 2017 
Sukajadi, K. 1993. Agama yang Berkembang di Dunia dan Para Pemeluknya, Bandung: Angkasa. Kepustakaan Nasional RI:Katalog dalam Terbitan (KDT), 2013. Pikukuh Tillu Ajaran Karuhun Urang, Bogor: Lembaga Pengkajian Kebudayaan Nusantara. 